\title{
4-Hydroxybutenolide impairs cell migration, and invasion of human oral cancer SCC-4 cells via the inhibition of NF-kB and MAPK signaling pathways
}

\author{
FU-SHUN YU ${ }^{1}$, MENG-LIANG LIN ${ }^{2}$, SHU-CHUN HSU ${ }^{3}$, CHIEN-CHIH YU ${ }^{4}$, \\ YI-PING HUANG ${ }^{5}$, YUEH-HSIUNG KUO ${ }^{6,7}$ and JING-GUNG CHUNG ${ }^{3,7}$
}

\begin{abstract}
${ }^{1}$ School of Dentist, Departments of ${ }^{2}$ Medical Laboratory Science and Biotechnology, and ${ }^{3}$ Biological Science and Technology, ${ }^{4}$ School of Pharmacy, Departments of ${ }^{5}$ Physiology and ${ }^{6}$ Chinese Pharmaceutical Sciences and Chinese Medicine Resources, China Medical University, Taichung; ${ }^{7}$ Department of Biotechnology, Asia University, Taichung, Taiwan, R.O.C.
\end{abstract}

Received March 16, 2016; Accepted April 27, 2016

DOI: 10.3892/ijo.2016.3537

\begin{abstract}
Hydroxybutenolide (K87), a synthetic compound from furfuryl alcohol via photooxidation, was used to investigate whether it can inhibit mobility, migration and invasion of SCC-4 human oral cancer cells in vitro. Cell viability was measured by flow cytometric assay, the enzymatic activities of MMP-2/9 were assayed by gelatin zymography analysis, the protein levels were assayed by western blotting, confocal laser microscopy and EMSA assay, and the gene expression of MMP-2/-7, FAK and ROCK1 mRNA were assayed by PCR. K87 decreased the percentage of viable cells in dosedependent manner. K87 suppressed cell mobility, migration and invasion of SCC-4 cells dose-dependently. K87 inhibited the enzymatic activities of MMP-2/9 of SCC- 4 cells. Western blot analysis revealed that K87 decreased the protein levels in NF- $\kappa$ Bp65, COX-2, ROCK1 and Rho A, MMP-1, -2,- 7, -9, VEGF, GRB2, SOS1, PI3K, PKC, PERK, p-PERK, FAK, MEKK3, MKK7, ERK1/2, JNK1/2, p-p38, p38, p-c-Jun, AKT, TIMP2, but increased the protein levels of iNOS, Ras, IRE-1 $\alpha$, p-c-JNK, p-AKT(308), p-AKT(473) and TIMP1. Results from PCR indicated that K87 inhibited the gene expression of MMP-2/-7, FAK and ROCK1 mRNA. Furthermore, confocal laser microscopy was used to confirm that $\mathrm{K} 87$ inhibited the translocation of RHOA and ROCK1 in SCC-4 cells. EMSA assay also show that $\mathrm{K} 87$ suppressed the nuclear activation of
\end{abstract}

Correspondence to: Professor Jing-Gung Chung, Department of Biological Science and Technology, China Medical University, 91 Hsueh-Shih Road, Taichung, Taiwan, R.O.C.

E-mail: jgchung@mail.cmu.edu.tw

Professor Yueh-Hsiung Kuo, Department of Chinese Pharmaceutical Sciences and Chinese Medicine Resources, China Medical University, 91 Hsueh-Shih Road, Taichung 404, Taiwan, R.O.C.

E-mail:kuoyh@mail.cmu.edu.tw

Key words: 4-Hydroxybutenolide, mobility, migration, invasion, SCC- 4 cells
NF- $\mathrm{kB}$ and these effects are time-dependent. Western blotting assay indicated that expression of NF- $\mathrm{\kappa Bp} 105, \mathrm{NF}-\kappa \mathrm{Bp} 50$ and NF- $\mathrm{\kappa Bp} 65$ proteins were decreased and these effects are timedependent. Based on these observations, we suggest that K87 may be used as a potential agent for anticancer metastasis of human oral cancer in the future.

\section{Introduction}

Head and neck cancer is the sixth most frequent cancer worldwide (1) and over $90 \%$ of head and neck cancer occurs in the oral cavity (2). Oral squamous cell carcinoma (OSCC) is a disease in the epithelial neoplasm with increased prevalence responsible for most malignant lesions in the head and neck. This disease represents only $\sim 3 \%$ of all malignancies of the human body (3), it can lead to invasion and metastasis to cause adverse complication for the prognosis and treatment with chemotherapy of patients. The inhibition of cancer cell metastasis is one of the critical steps to therapy and research in human cancer (4). The identification of molecular pathways involved in cancer cell metastasis plays an important role for anticancer function of pharmacologic compounds (5).

Tumor metastasis is one of the major causes of morbidity and mortality in cancer patients. Molecular mechanisms of cancer cell metastasis are involved a series of molecular events such as the tumor cell-induced extracellular matrix (ECM) which provides biochemical and mechanical barriers (6), ECM component binding and angiogenesis are involved in cancer cell metastatic processes, degradation of basement membrane of ECM is a critical step in the processes of tumor metastasis $(7,8)$. Matrix metalloproteinases (MMPs) play a critical role in ECM degradation and these enzymes are considered to be essential factors involved in tumor metastasis such as MMP-2 and -9 $(8,9)$ and MMP-9 is considered to be one of the critical MMPs involved in cancer invasion in breast cancer $(10,11)$. The inhibition of MMP-2 and/or MMP-9 expression, or their upstream regulatory pathways could be one of the treatment options for patients with cancer.

Nuclear factor- $\kappa \mathrm{B}(\mathrm{NF}-\kappa \mathrm{B})$ signaling pathway plays an important role in cancer cell escape from anticancer drug 
A
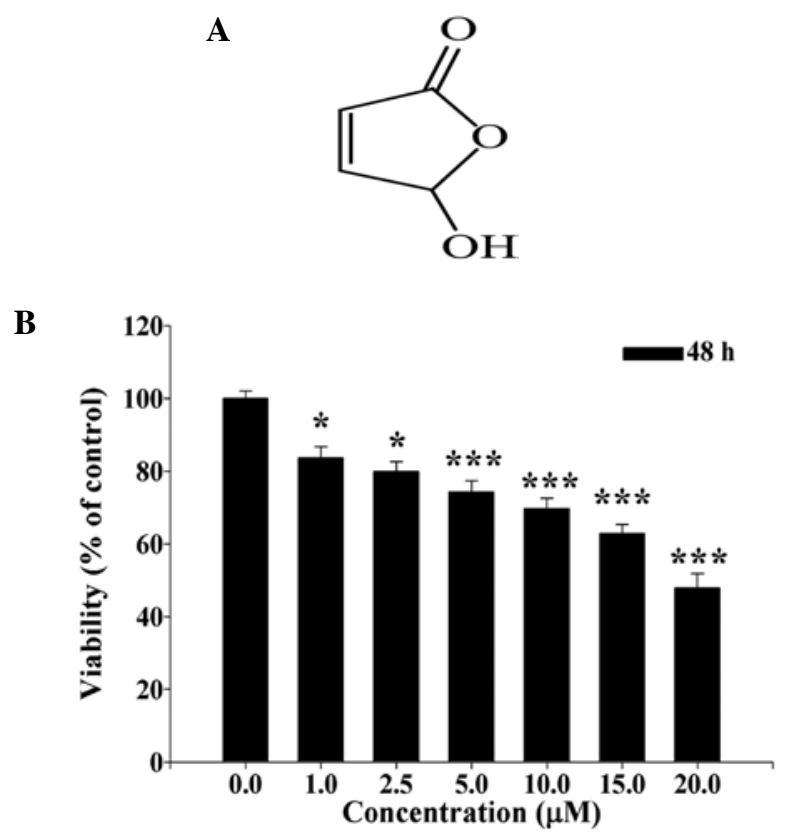

Figure 1. K87 decreased the percentage of viable human oral cancer SCC-4 cells. (A) Chemical structure of K87. Cells ( $1 \times 10^{5}$ cells/well) were incubated with $\mathrm{K} 87$ at the final concentrations $(0,1,2.5,5,10,15$ and $20 \mu \mathrm{M})$ or $0.5 \%$ dimethyl sulfoxide (DMSO as a vehicle control for $48 \mathrm{~h}$ before cells were harvested and the percentage of viable cells were determined by flow cytometry and percentage of inhibition (B) was calculated as described in Materials and methods. ${ }^{*} \mathrm{P}<0.05,{ }^{* * *} \mathrm{P}<0.001$ significant difference between K87 treated groups and the control as analyzed by the Student's t-test.

induced cell apoptosis and resistance of chemotherapy in many human cancer cells including head and neck cancer $(12-16)$. $\mathrm{NF}-\kappa \mathrm{B}$ is restricted by the inhibitory protein $\mathrm{I} \kappa \mathrm{B}$ and after $I \kappa B$ is phosphorylated, $N F-\kappa B$ is liberated which enter the nucleus to regulate gene expression involved in cell proliferation, cell survival and apoptosis $(17,18)$. NF- $\kappa \mathrm{B}$ is associated with cancer cell invasion and metastasis in various cancers (19-22).

Akt is involved in the progression of metastasis through various signaling mechanisms such as $\mathrm{NF}-\kappa \mathrm{B}$, which is a direct target of Akt (23). Activator protein-1 (AP-1), NF- $\kappa \mathrm{B}$ via mitogen-activated protein kinase (MAPK) or phosphatidylinositol 3-kinase (PI3K)/Akt pathways led to regulation of the expression of the MMPs gene $(24,25)$. MMPs and their regulatory pathways were the targets for anticancer drugs and chemotherapeutic agents (26). The aim of the present study was to investigate the molecular mechanisms of K87 suppressing the migration and invasion of human oral cancer SCC-4 cells. This is the first study that the anti-metastatic activity of K87 involves $\mathrm{NF}-\kappa \mathrm{B}$ and MMP-2/9 inhibition in human oral cancer SCC-4 cells in vitro.

\section{Materials and methods}

Chemicals and reagents. K87, a synthetic compound from furfuryl alcohol by photoxidation (27) was obtained from the laboratory of Dr Y.-H. Kuo, and the chemical structure is shown in Fig. 1. Dimethyl sulfoxide (DMSO) and propidium iodide (PI) were purchased from Sigma-Aldrich (St. Louis, MO, USA). All primary and secondary antibodies were purchased from Santa Cruz Biotechnology, Inc. (Santa Cruz,
CA, USA). The enhanced chemiluminescence (ECL) detection system was obtained from Amersham Life Science, Inc. (Arlington Heights, IL, USA).

Cell culture. Human oral cancer SCC-4 cells were purchased from the Food Industry Research and Development Institute (Hsinchu, Taiwan). Cells were cultured in DMEM:F12 medium (Gibco-Life Technologies, Carlsbad, CA, USA) containing $10 \%$ fetal bovine serum and antibiotics (100 units/ml penicillin and $100 \mu \mathrm{g} / \mathrm{ml}$ streptomycin) (Sigma-Aldrich) on a $75-\mathrm{cm}^{2}$ tissue culture flasks in a humidified atmosphere of $5 \% \mathrm{CO}_{2}$ at $37^{\circ} \mathrm{C}(28,29)$.

Cell viability assays. SCC-4 cells ( $1 \times 10^{5}$ cells/well) were placed in a 12-well plate for $24 \mathrm{~h}$ and were incubated with K87 $(0,1,2.5,5,10,15$ and $20 \mu \mathrm{M})$ or $0.5 \%$ DMSO as a vehicle control for $48 \mathrm{~h}$. Cells were stained with PI $(5 \mu \mathrm{g} / \mathrm{ml})$ and then viability was immediately measured using flow cytometer (FACSCalibur; BD Biosciences, San Jose, CA, USA) assay as previously described (28).

Wound healing assay. Cells $\left(1.5 \times 10^{5}\right.$ cells/well) were placed in a 6 -well plate and incubated at $37^{\circ} \mathrm{C}$ for $24 \mathrm{~h}$. The confluent cells were scratched with a $200 \mu$ l pipette tip, followed with PBS washing, and then treated with $\mathrm{K} 87(0,1$ and $2.5 \mu \mathrm{M})$ in a serum-free medium for 12 and $24 \mathrm{~h}$. Cells were examined and photographed under a fluorescence microscope (Axio Observer A1; Carl Zeiss, Oberkochen, Germany). The total number of cells migrated into the scratched area was calculated (30).

Cell migration and invasion assays. For cell migration assay, Transwell (BD Biosciences, Franklin Lakes, NJ, USA) cell culture chambers ( $8 \mathrm{~mm}$ pore size; Millipore, Billerica, MA, USA) were coated with collagen and SCC- 4 cells $\left(5 \times 10^{4}\right.$ cells/well) were maintained in serum-free DMEM:F12 medium overnight, while cells were trypsinized and resuspended in serum-free DMEM:F12 medium. In the upper chamber of the Transwell insert, cells were placed and incubated with $0.5 \%$ DMSO or K87 (1 and $2.5 \mu \mathrm{M})$. A total of 90\% DMEM:F12 medium containing $10 \%$ FBS were maintained in the lower chamber. All cells were incubated for 24 or $48 \mathrm{~h}$. The migrative cells in the lower surface of the filter were fixed with $4 \%$ formaldehyde in PBS and were stained with $2 \%$ crystal violet. Cell number were counted and photographed under a light microscope at $\mathrm{x} 200$. Cell invasion assay was done as the cell migration assay except the filter membrane was coated with Matrigel from a BioCoat Matrigel invasion kit not for collagen as previously described $(30,31)$.

Gelatin zymography assay. SCC- 4 cells $\left(1.5 \times 10^{5}\right.$ cells/well $)$ were seeded in 6-well plate for $24 \mathrm{~h}$ and then were incubated with $\mathrm{K} 87(0,0.25,0.5,1$ and $2.5 \mu \mathrm{M})$ in serum-free DMEM:F12 medium for 24 and $48 \mathrm{~h}$ and the conditioned medium was collected and the total proteins measured. A total of $50 \mu \mathrm{g}$ of protein was separated on $10 \%$ SDS-PAGE containing $0.2 \%$ gelatin by electrophoresis. After electrophoresis, the gels were washed with $2.5 \%$ Triton $\mathrm{X}-100$ and incubated in a reaction buffer $(50 \mathrm{mM}$ Tris- $\mathrm{HCl}, \mathrm{pH} 7.5$, $0.02 \% \mathrm{NaN}_{3}, 150 \mathrm{mM} \mathrm{NaCl}, 10 \mathrm{mM} \mathrm{CaCl}{ }_{2}, 1 \mu \mathrm{M} \mathrm{ZnCl}_{2}$ ) for 
$18 \mathrm{~h}$ at $37^{\circ} \mathrm{C}$ while shaking. After incubation, the gels were stained with $0.2 \%$ Coomassie blue in $10 \%$ acetic acid and $50 \%$ methanol (31-33). Both MMP-2/-9 gelatinolytic activities were visualized as the presence of clear bands with a blue (negative staining) background.

Western blotting assay. SCC-4 cells $\left(1.5 \times 10^{6}\right.$ cells $)$ in $10-\mathrm{cm}$ dish were incubated with $\mathrm{K} 87(0$ and $2.5 \mu \mathrm{M})$ for $6,12,24$ and $48 \mathrm{~h}$. Cells were collected, washed, centrifuged and lysis buffer [40 mM Tris- $\mathrm{HCl}$ ( $\mathrm{pH}$ 7.4), 10 mM EDTA, $120 \mathrm{mM} \mathrm{NaCl}$, $1 \mathrm{mM}$ dithiothreitol, $0.1 \%$ Nonide P-40] was added to the cell pellet for $30 \mathrm{~min}$. In each sample protein was quantitated as previously described $(32,34)$. A total of $30 \mu \mathrm{g}$ of protein was loaded on a gel [10\% sodium dodecyl sulphate (SDS)/ polyacrylamide] for western blot analysis. The gel was transferred onto a nitrocellulose membrane (Amersham Pharmacia Biotech, Piscataway, NJ, USA) by electro-blotting at $300 \mathrm{~mA}$ for 90 min. After blocking with $5 \%$ non-fat skim milk, the membrane was probed with primary antibodies against NF-кBp65, iNOS, COX-2, ROCK1, Rho A, MMP-1, -2,- 7, -9, VEGF, GRB2, Ras, SOS1, PI3K, PKC, PERK, p-PERK, IRE-1 $\alpha$, FAK, MEKK3, MKK7, ERK1/2, JNK1/2, p-c-JNK, p-p38, p38, p-c-Jun, AKT, p-AKT(308), p-AKT(473), TIMP2, TIMP1 and $\beta$-actin. After incubation, membrane was stained with secondary antibody for enhanced chemiluminescence (Amersham Life Science) as previously described $(32,34)$. The antibody binding was detected by enhanced chemiluminescene (ECL) procedures according to the manufacturer's recommendation.

Real-time polymerase chain reaction (PCR). SCC-4 cells $\left(1.5 \times 10^{5}\right.$ cells/well $)$ were seeded onto 6 -well culture plates and incubated with $\mathrm{K} 87(0$ and $2.5 \mu \mathrm{M})$ for $24 \mathrm{~h}$ and were collected and total RNA was extracted using the Qiagen RNeasy Mini kit (Qiagen, Valencia, CA, USA) as previously described $(35,36)$. Total RNA was reverse-transcribed with High Capacity cDNA Reverse Transcription kit at $42^{\circ} \mathrm{C}$ for $30 \mathrm{~min}$ according to the standard protocol of the supplier (Applied Biosystems, Foster City, CA, USA). All samples for quantitative PCR were done under the following conditions: $2 \mathrm{~min}$ at $50^{\circ} \mathrm{C}, 10 \mathrm{~min}$ at $95^{\circ} \mathrm{C}$ and 40 cycles of $15 \mathrm{sec}$ at $95^{\circ} \mathrm{C}, 1 \mathrm{~min}$ at $60^{\circ} \mathrm{C}$ using $1 \mathrm{ml}$ of the reverse-transcribed cDNA, 2X SYBRGreen PCR Master Mix (Applied Biosystems) and $200 \mathrm{nM}$ of forward (F) and reverse (R) primers, including MMP-2: F-CCCCAGACAGGTGATCTTGAC and R-GCTTGC GAGGGAAGAAGTTG; MMP-9: F-CGCTGGGCTTAG ATCATTCC and R-GTGCCGGATGCCATTCAC; FAK: F-TGAATGGAACCTCGCAGTCA and R-TCCGCATGC CTTGCTTTT; ROCK1-F-ATTCATTCCTACCCTCTACC ACTTTC and R-TGTGGGACTTAACATGGCATCT; glyceraldehyde 3-phosphate dehydrogenase (GAPDH): F-ACACC CACTCCTCCACCTTT and R-TAGCCAAATTCGTTGTC ATACC. Each assay was run in triplicate on an Applied Biosystems 7300 Real-Time PCR system and expression foldchanges were derived using comparative CT method $(35,36)$.

Confocal laser scanning microscopy. SCC-4 cells $\left(1.5 \times 10^{5}\right.$ cells/well) were maintained in 6-well chamber slides and were incubated with $\mathrm{K} 87(0$ and $2.5 \mu \mathrm{M})$ for $24 \mathrm{~h}$. All samples were fixed for $15 \mathrm{~min}$ with $3 \%$ formaldehyde in PBS and labeled for immunofluorescence. Primary antibodies against RHO A and ROCK1 were diluted 1:100 with blocking buffer. They were washed with PBS, and were stained with secondary FITCconjugated goat anti-mouse IgG at 1:200 dilutions (green fluorescence). Cell nuclei were counterstained with PI (red fluorescence) and then were examined and photomicrographed using a Leica TCS SP2 confocal spectral microscope as previously described $(32,37)$.

Electrophoretic mobility shift assay (EMSA). SCC-4 cells $\left(1.5 \times 10^{6}\right.$ cells $/ 10-\mathrm{cm}$ dish) were treated with K87 (0 and $2.5 \mu \mathrm{M}$ ) for $0,2,4$ and $8 \mathrm{~h}$. After incubation, NE-PER Nuclear and Cytoplasmic Extraction kit (Pierce) was used to perform nuclear extracts as previously described $(38,39)$ and protein concentration was measured and biotin end-labeled oligonucleotide sequences were 50-BiotinGATCCAGGGGACTTTCCCTAGC-30 corresponding to the consensus site of NF- $\kappa \mathrm{B}$. A total of $5 \mu \mathrm{g}$ of nuclear extract protein was used for EMSA with LightShift Chemiluminescent EMSA kit based on the manufacturer's protocol. The nuclear extracts was incubated with Biotin end-labeled duplex DNA and the reaction mixture was separated on $6.0 \%$ polyacrylamide gel electrophoresis, and transferred onto nylon membranes which were subjected to ultraviolet (UV) light cross-link for $1 \mathrm{~min}$. Membrane was incubated with blocking buffer containing stabilized streptavidin-horseradish peroxidase conjugate $(1: 2,000)$ incubated with the substrates of the ECL kit for $15 \mathrm{~min}$. The NF- $\kappa \mathrm{B}$ signals on the membranes were detected using Chemiluminesent Nucleic Acid Detection Module (Pierce Biotechnology).

Preparation of cytosolic and nuclear extracts. SCC-4 cells were treated with $\mathrm{K} 87(0$ and $2.5 \mu \mathrm{M})$ for $0,2,4,6$ and $8 \mathrm{~h}$. Cells were washed twice with ice-cold PBS and then immediately were suspended with the lysis buffer (0.1 mM EDTA, $1 \mathrm{mM}$ DTT, $10 \mathrm{mM}$ HEPES pH 7.9, 0.1 mM EDTA, $10 \mathrm{mM}$ $\mathrm{KCl}, 1 \mathrm{mM}$ phenylmethylsulfonyl fluoride) for $20 \mathrm{~min}$ and was added $4.8 \mu \mathrm{l}$ of $10 \% \mathrm{NP}-40$ to the cells and vigorously mixing for $30 \mathrm{sec}$. After centrifugation at 13,000 x g under $4^{\circ} \mathrm{C}$ for $15 \mathrm{~min}$, there were divided into two parts, one was the cytosolic fractions (cytosolic extracts) (40). The other part was the nuclear pellets which were re-suspended in $25 \mu 1$ of sample buffer named nuclear extracts. Both proteins in the cytosolic and nuclear extracts were quantitated and were detected by western blotting with $10 \%$ SDS-polyacrylamide gel (PAGE) for $\mathrm{NF}-\kappa \mathrm{Bp} 105, \mathrm{NF}-\kappa \mathrm{Bp} 50$ and $\mathrm{NF}-\kappa \mathrm{Bp} 65$ protein expression level as previously described $(32,34)$.

Statistical analysis. All assays were performed in triplicate and data are expressed as means \pm SD. Statistically significant differences between K87 treated and untreated (control) groups were tested by the Student's t-test. A P $<0.05$ was considered to indicate significant differences.

\section{Results}

K87 decreased the cell viability of human oral cancer SCC-4 cells. SCC-4 cells were treated with $\mathrm{K} 87$ (0, 1, 2.5, 5, 10, 15 and $20 \mu \mathrm{M}$ ) for $48 \mathrm{~h}$ and total percentage of viable cells were measured and the results are shown in Fig. 1B. As shown 
A
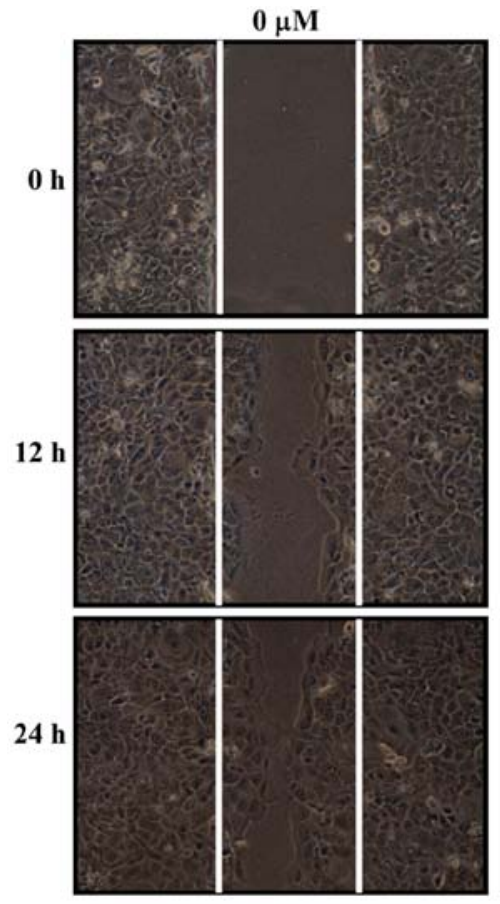

$1 \mu \mathbf{M}$
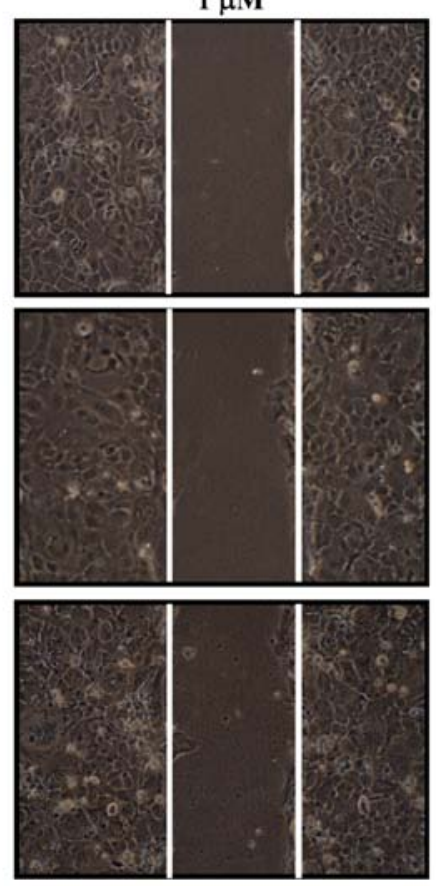

$2.5 \mu \mathrm{M}$
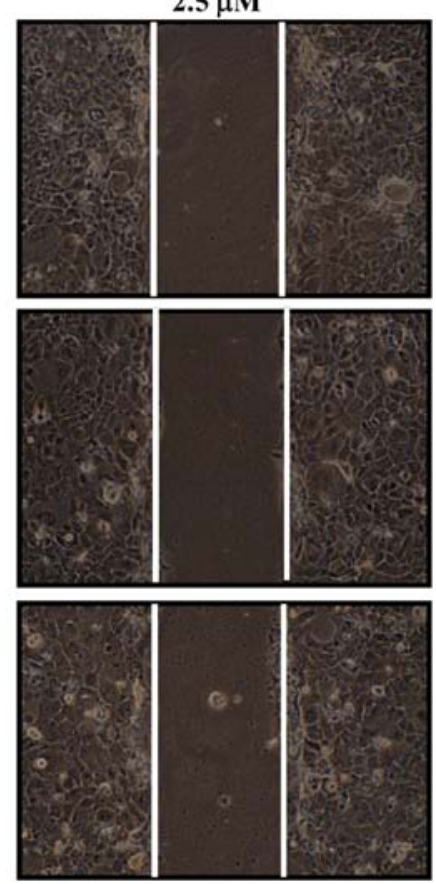

B

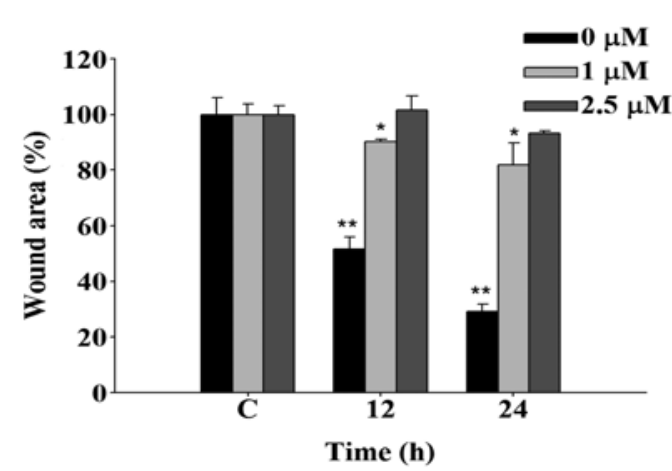

D

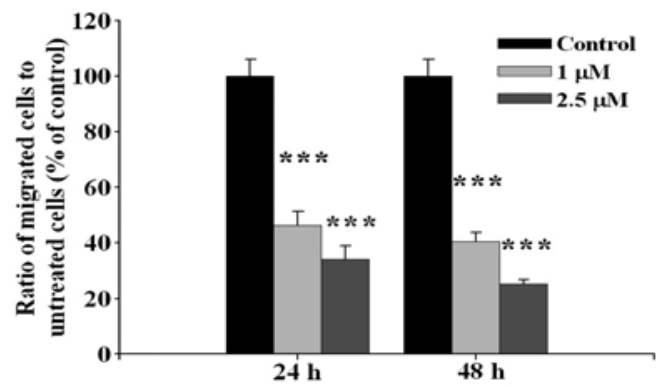

C
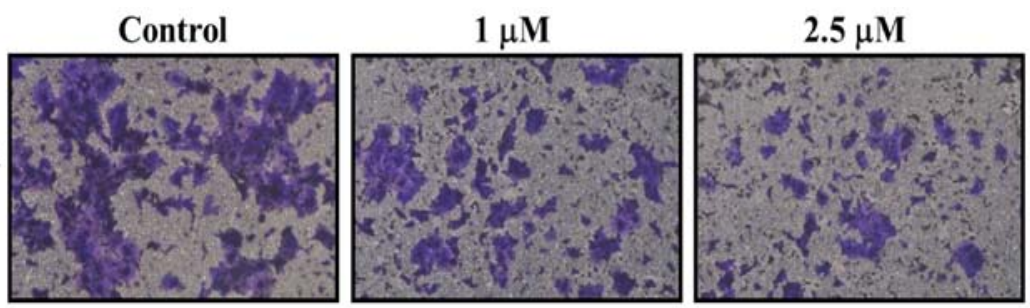

$48 \mathrm{~h}$
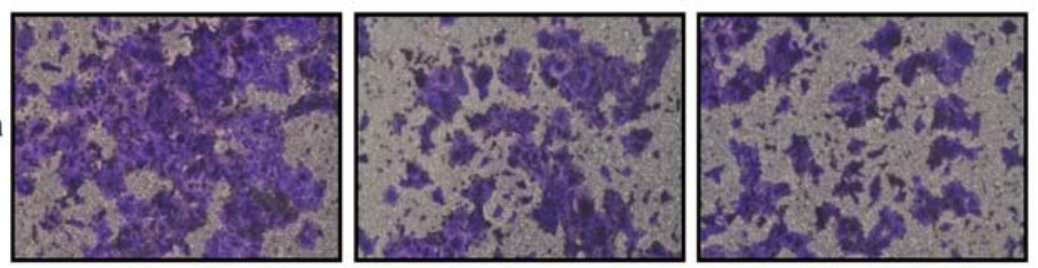

$\mathbf{E}$

Control

$1 \mu \mathbf{M}$

$2.5 \mu \mathrm{M}$

$24 \mathrm{~h}$
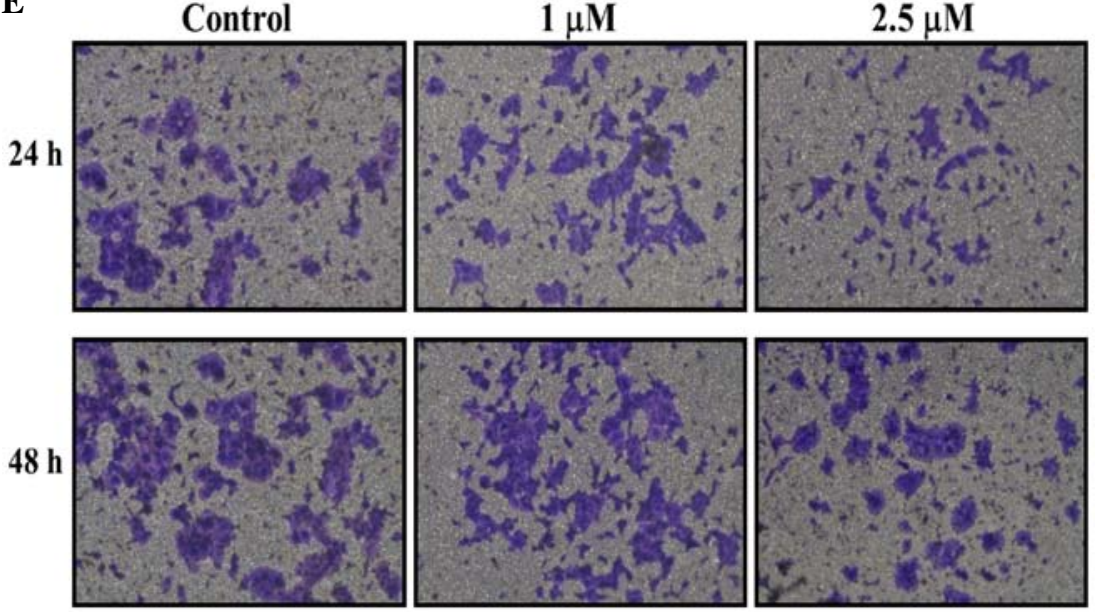

Figure 2. K87 suppressed the mobility, migration and invasion and activities of MMP-2/-9 of SCC-4 cells. Cells (1.5x10 5 cells/well) were placed in a 6-well plate and incubated at $37^{\circ} \mathrm{C}$ for 12 and $24 \mathrm{~h}$. The confluent cells were scratched with a $200-\mu 1$ pipette tip and then treated with 0,1 and $2.5 \mu \mathrm{M}$ in a serum-free medium for 12 and $24 \mathrm{~h}$. After treatment, the cells were examined and photographed under a fluorescence microscope (A). The total number of cells migrated into the scratched area was calculated (B). Cells $\left(5 \times 10^{4}\right.$ cells/well) were placed on filter which is coated with collagen and were incubated with K87 (0, 1.0 and $2.5 \mu \mathrm{M}$ ) for 24 and $48 \mathrm{~h}$. Then they penetrated through to the lower surface of the filter which were stained with crystal violet and were photographed under a light microscope at x200 (C) and the cells were counted and percentage of inhibition were calculated (D). Cells penetrated through with the Matrigel to the lower surface of the filter were stained with crystal violet and were photographed under a light microscope at x200 (E). 


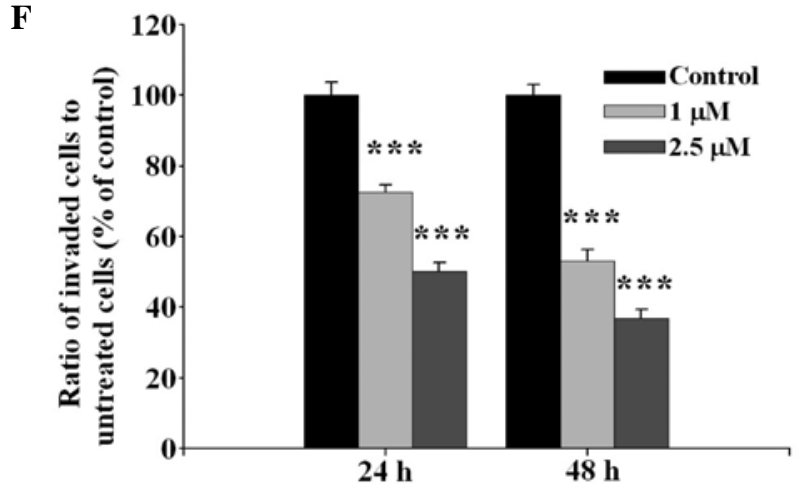

G
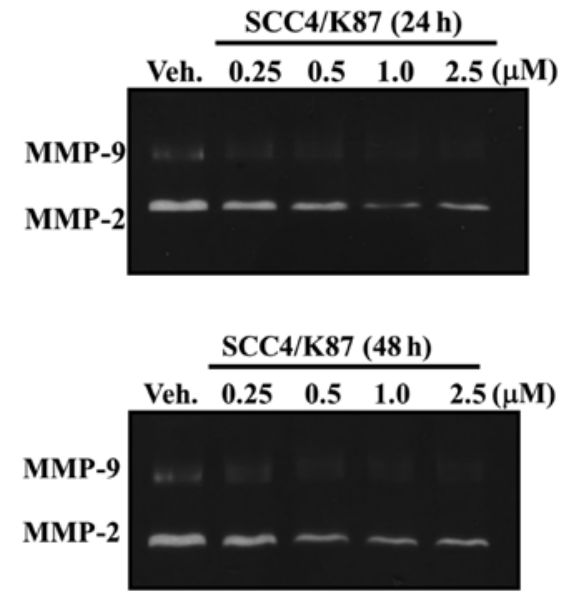

Figure 2. Continued. (F) Cells were counted and percentage of inhibition were calculated. Cells $\left(1.5 \times 10^{5}\right.$ cells/well $)$ were incubated with $0,0.25,0.5$, 1.0 and $2.5 \mu \mathrm{M}$ of $\mathrm{K} 87$ for 24 and $48 \mathrm{~h}$ and then conditioned medium was collected and gelatin zymography performed as described in Materials and methods. The different activity of MMP-2/-9 were determined by densitometric analysis and the results are expressed as a percentage of the control $(100 \%)(G)$. Results were obtained from three independent experiments. ${ }^{*} \mathrm{P}<0.05,{ }^{* * *} \mathrm{P}<0.001$ significant difference between K87-treated groups and the control as analyzed by Student's t-test.

in Fig. 1B, K87 caused dose-dependent inhibition of the growth of SCC-4 cells in the 48-h treatment, with the various concentrations $(1-20 \mu \mathrm{M})$ giving rise to between 18 and $56 \%$ inhibition.

K87 inhibited cell mobility, migration and invasion and activities of MMP-2/-9 of SCC-4 cells. Results from Fig. 1B indicated that $\mathrm{K} 87$ at $>5 \mu \mathrm{M}$ decreased over $25 \%$ cell viability, thus, we selected 1 and $2.5 \mu \mathrm{M}$ for wound healing assay and results are shown in Fig. 2A and B. After treatment with $2.5 \mu \mathrm{M} \mathrm{K} 87$ for 12 and $24 \mathrm{~h}$, cells remained creviced, while untreated wounds healed better. At higher concentrations and longer time of treatment of K87 both have higher inhibition of cell mobility (Fig. 2A and B). Transwell cell migration and invasion assays were used for investigating the inhibition of $\mathrm{K} 87$ on cell migration and invasion and results are present in Fig. 2C-F. K87 significantly inhibited cell migration by 52 and $64 \%$ at $24 \mathrm{~h}$ and 58 and $76 \%$ at $48 \mathrm{~h}$ both for 1.0 and $2.5 \mu \mathrm{M}$ of $\mathrm{K} 87$ treatment (Fig. 2C and D). K87 significantly inhibited cell invasion by 24 and $47 \%$ for $24 \mathrm{~h}$, and 42 and $67 \%$ for $48 \mathrm{~h}$ both for 1.0 and $2.5 \mu \mathrm{M}$ of K87 treatment (Fig. 2E and F). Inhibition of migration and inva- sion in SCC-4 cells was concentration- and time-dependent. Gelatin zymography was performed to detect the gelatinolytic activity in conditioned media of SCC- 4 cells treated by $\mathrm{K} 87$ and results are shown in Fig. 2G. K87 was markedly effective in inhibiting the gelatinolytic activity of MMP-2/-9. MMP-2/-9 activities were observed to be decreased in a dose- and timedependent manner.

K87 affects the expression of migration and invasion associated proteins in SCC-4 cells. We have found that $\mathrm{K} 87$ suppressed cell mobility, migration and invasion, thus, we evaluated the expression of these molecules in SCC-4 cells. Western blot analysis revealed that $\mathrm{K} 87$ decreased the protein levels in NF-кBp65, COX-2, ROCK1 and Rho A (Fig. 3A), MMP-1, -2,- 7, -9 and VEGF (Fig. 3B), GRB2, SOS1, PI3K, PKC, PERK and p-PERK (Fig. 3C), FAK, MEKK3, MKK7, ERK1/2, JNK1/2, p-p38 and p38 (Fig. 3D), p-c-Jun, AKT and TIMP2 (Fig. 3E), but increased the protein levels of iNOS (Fig. 3A), Ras and IRE-1 $\alpha$ (Fig. 3C), p-c-JNK (Fig. 3D), p-AKT(308), p-AKT(473) and TIMP1 (Fig. 3E). Those findings indicated that $\mathrm{K} 87$ affected cell mobility, migration, invasion, angiogenesis and metastasis associated protein in SCC-4 cells. The expressions of majority of proteins were downregulated by $\mathrm{K} 87$ in a time-dependent manner in SCC-4 cells.

K87 downregulates the $m R N A$ expression of MMP-2 and -7 , FAK and ROCK1 in SCC-4 cells. RT-PCR was performed for an inhibitory effect of $\mathrm{K} 87$ on the protein expression of $M M P-2$ and -7, FAK and ROCK1 via the depressed the levels of $M M P-2$, and -7, FAK and ROCK1 mRNAs expression and results are shown in Fig. 4 . K87 $(2.5 \mu \mathrm{M})$ significantly downregulated $M M P-2$ and $-7, F A K$ and $R O C K 1 \mathrm{mRNA}$ expressions by $25,91,72$ and $17 \%$, respectively, in SCC- 4 cells. The highest inhibition of mRNA expression was in $M M P-7$. We suggested that K87 downregulated expression of MMP-2 and -7, FAK and $R O C K 1$ at the transcriptional level.

K87 alters translocation of RHOA and ROCK1 in SCC-4 cells. RHOA and ROCK1 nuclear translocation was examined with confocal microscopy immunofluorescent imaging technique (Fig. 5). K87 treated SCC-4 cells were significantly decreased in the presence of RHOA (Fig. 5A) and ROCK1 (Fig. 5B) in the nuclei. The functional consequence and the underlying mechanism of the nuclear RHOA and ROCK1 translocation in cancer cells needs further investigations.

$K 87$ affects $N F-\kappa B$ DNA binding activity and protein expressions in $\mathrm{SCC}-4$ cells. Western blotting showed that K87 inhibited the expression of $\mathrm{NF}-\kappa \mathrm{B}$ in SCC-4 cells (Fig. 3A). Thus, for further understanding the $\mathrm{NF}-\kappa \mathrm{B}$ binding, we used EMSA assay and the results are shown in Fig. 6A. K87 suppressed the nuclear activation of $\mathrm{NF}-\kappa \mathrm{B}$ and these effects are time-dependent. Cells were treated with $\mathrm{K} 87(2.5 \mu \mathrm{M})$ for 2, 4 and $8 \mathrm{~h}$, then harvested for cytosolic and nuclear extracts for western blotting assay and results are shown in Fig. 6B and C. IKK, p-IKK and IкB (Fig. 6B), NF-кBp105, $\mathrm{NF}-\kappa \mathrm{Bp} 50$ and $\mathrm{NF}-\kappa \mathrm{Bp} 65$ protein expression (Fig. 6C) was decreased in agreement with the results from EMSA assay which shown that K87 suppressed the nuclear activation of $\mathrm{NF}-\kappa \mathrm{B}$ (Fig. 6A). 
A

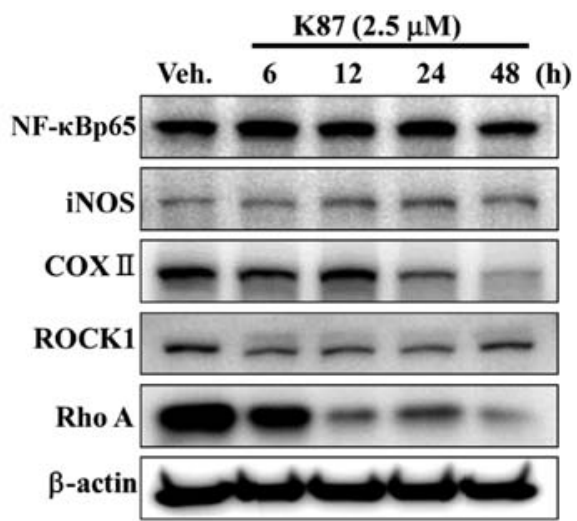

C

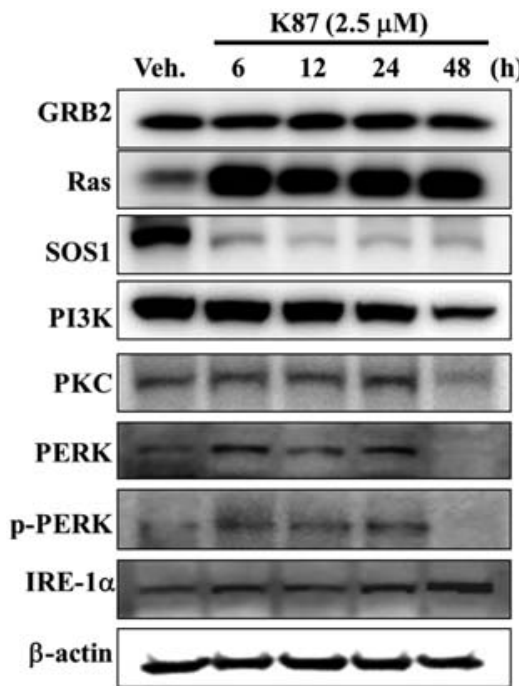

$\mathbf{E}$

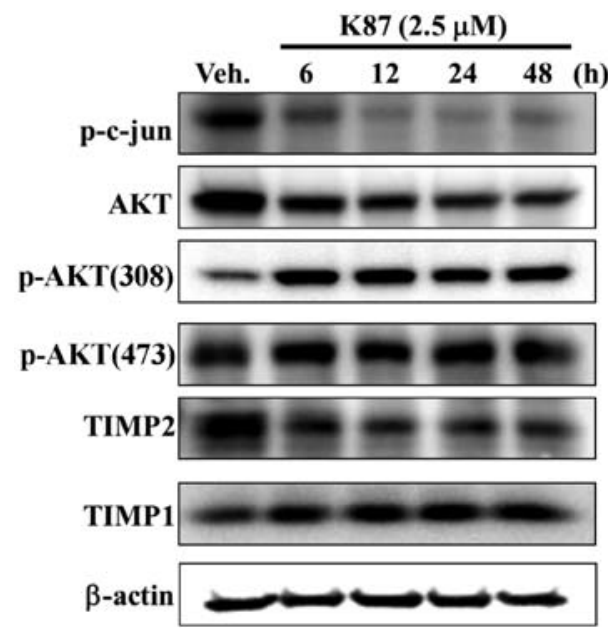

\section{Discussion}

Oral cancer is highly prevalent among the human population and is one of the most common cancers in males in Taiwan. Surgery, radiotherapy and chemotherapy has improved survival rates in the early stage of this disease, but the local recurrences and distant metastases are still a serious problem for oral cancer patients. Currently, novel therapeutic strategies and new drugs for defeating oral cancer cell metastases are essential. Cancer metastasis is a multistep process including cell mobility, migration, invasion, intravasation, entry into
B

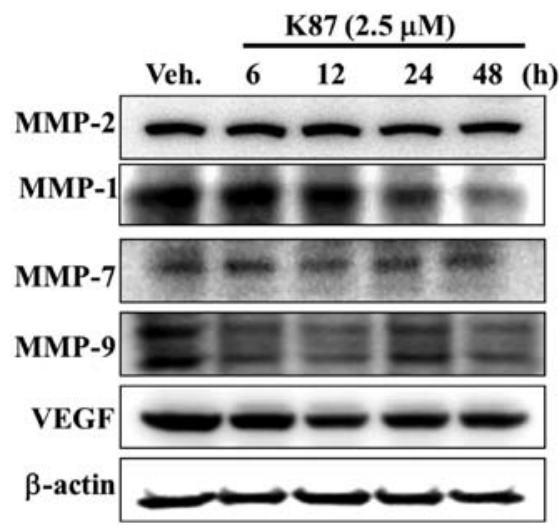

D

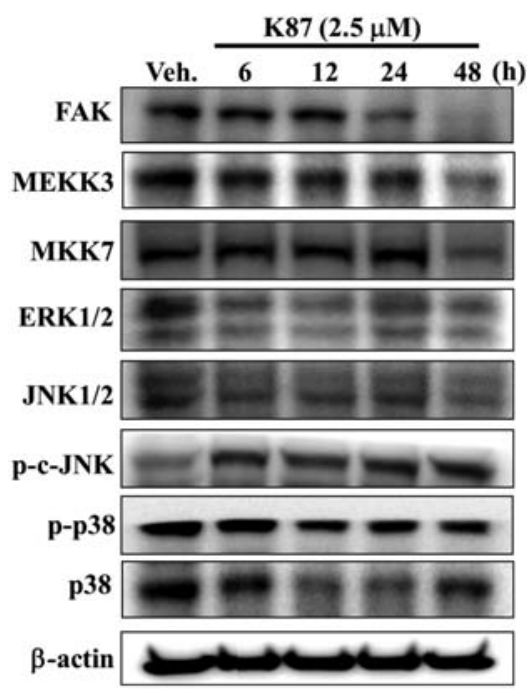

Figure 3. K87 affects the levels of associated proteins in migration and invasion of SCC- 4 cells. Cells $\left(1.5 \times 10^{5}\right.$ cells/dish) were treated with K87 of 0 and $2.5 \mu \mathrm{M}$ for $0,6,12,24$ and $48 \mathrm{~h}$ and then proteins were determined and were used for SDS page gel electrophoresis as described in Materials and methods. The levels of NF- $\mathrm{kBp} 65$, iNOS, COX-2, ROCK1 and Rho A (A), MMP-1, -2,- 7, -9 and VEGF (B), GRB2, SOS1, PI3K, PKC, PERK, p-PERK, Ras and IRE-1 $\alpha$ (C), FAK, MEKK3, MKK7, ERK1/2, JNK1/2, p-c-JNK, p-p38 and p38 (D), p-c-Jun, p-AKT(308), p-AKT(473), AKT and TIMP2 and TIMP1 (E) expression was, respectively, estimated by western blotting as described in Materials and methods.

blood or lymphatic vessel, extravasation, and developing new tumors in other organs (41) that make it more difficult to treat patient, and account for the main causes of death in cancer patients with treatment failure.

We investigated the pharmacological activity of $\mathrm{K} 87$ on SCC-4 cell mobility, migration and invasion. Our findings demonstrated that: i) K87 decreased total cell viability (Fig. 1B), suppressed cell mobility (Fig. 2A and B), migration and invasion (Fig. 2C and D) and inhibited MMP-2 and -9 activities (Fig. 2G); ii) K87 inhibited cell migration and invasion associated protein expression (Fig. 3E); iii) K87 downregulates the 


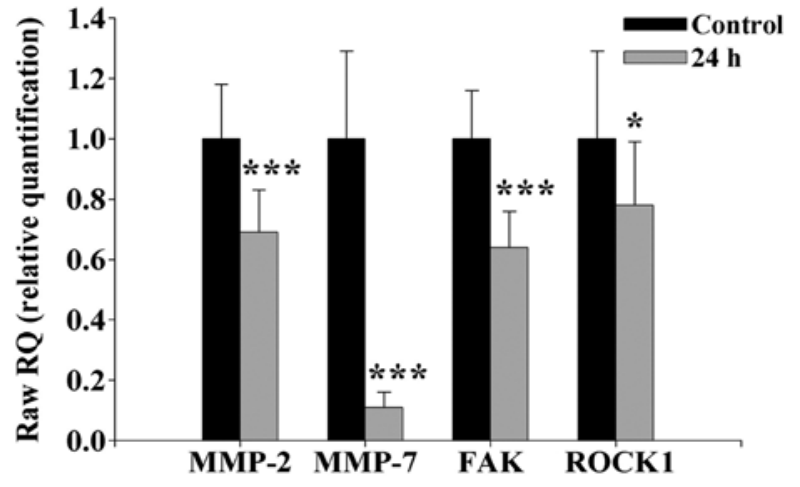

Figure 4. K87 inhibits the gene expression of MMP-2, MMP-7, FAK and ROCK1 in SCC- 4 cells. SCC- 4 cells $\left(1.5 \times 10^{5}\right.$ cells/well $)$ were seeded onto 6-well culture plates and incubated with $2.5 \mu \mathrm{M}$ of K87 for $24 \mathrm{~h}$. Cells were collected and total RNA was extracted and was reverse-transcribed with High Capacity cDNA Reverse Transcription kit. All samples underwent quantitative PCR as described in Materials and methods.
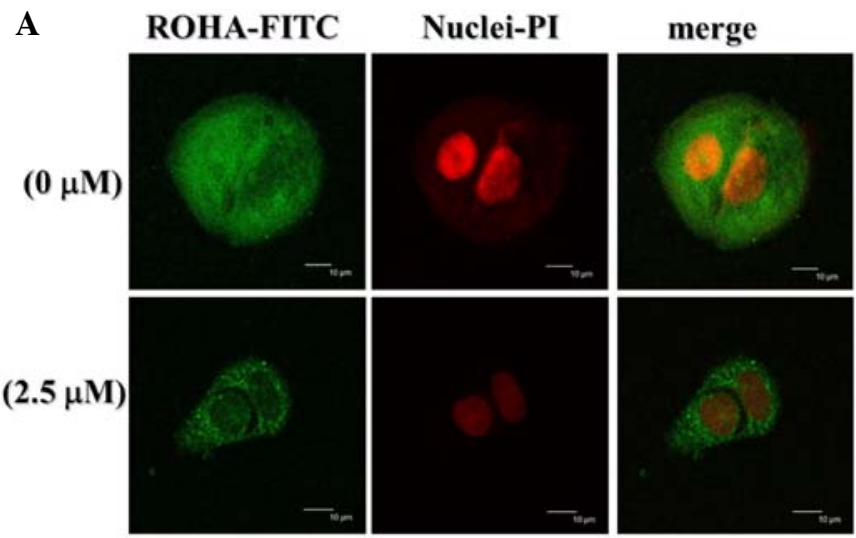

B
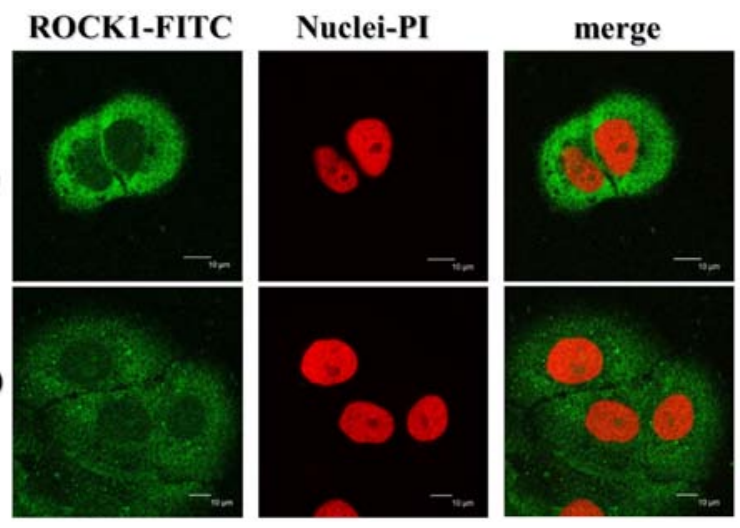

Figure 5. K87 affects translocation of RHOA and ROCK1 expression in SCC- 4 cells. Cells $\left(1.5 \times 10^{5}\right.$ cells/well) were placed on 6-well chamber slides and were treated with $\mathrm{K} 87(0$ and $2.5 \mu \mathrm{M})$ for $24 \mathrm{~h}$, fixed and stained using anti-RHOA (A) and ROCK1 (B) antibodies (1:100) overnight and then stained with a secondary antibody (FITC-conjugated goat anti-mouse IgG at 1:100 dilution) (green fluorescence) followed by PI (red fluorescence) staining nuclei. Photomicrographs were obtained using a Leica TCS SP2 confocal spectral microscope as described in Materials and methods.

mRNA expression of MMP-2 and -7, FAK and ROCK1 (Fig. 4); iv) K87 alters translocation of RHOA and ROCK1 in SCC-4 cells (Fig. 5); v) K87 affects NF- $\mathrm{kB}$ DNA binding activity in SCC-4 cells in vitro (Fig. 6A) and inhibited the expression of NF- $\mathrm{kB}$ proteins (Fig. 6B and C) in SCC-4 cells.
A

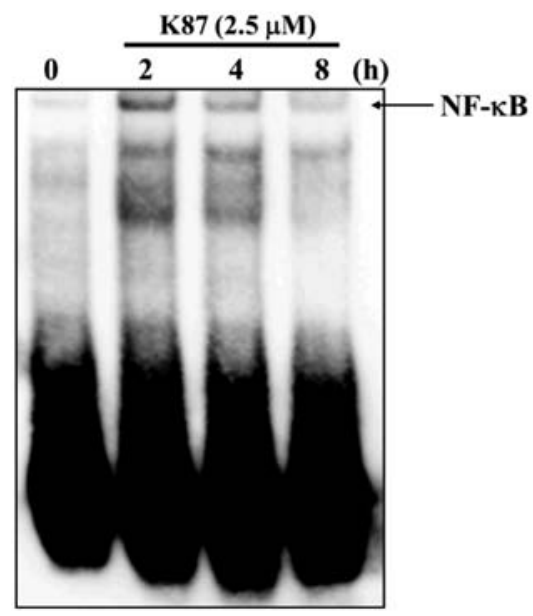

B

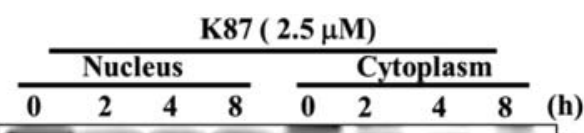

IKK $\alpha / \beta(H 470)$

p-IKK $\alpha / \beta$ (Ser176)

p-IKK $\alpha / \beta(T h r 23)$
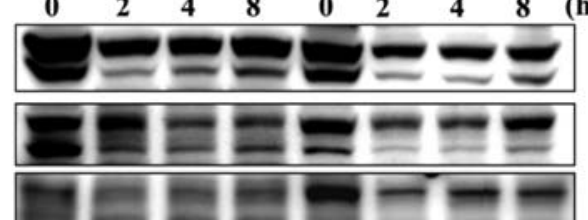

IкB- $\alpha$

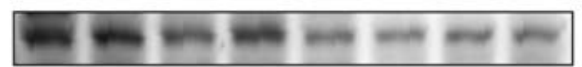

p-IкB- $\alpha$

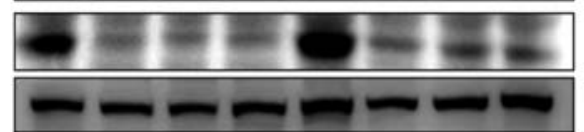

C

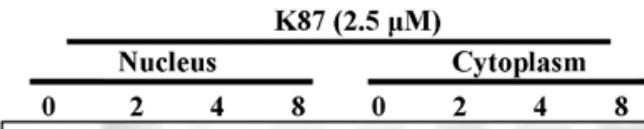

NF-кBp105
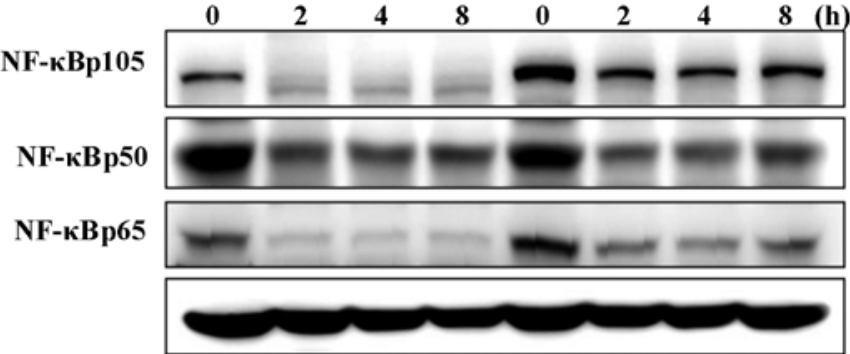

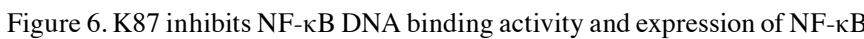
proteins in SCC- 4 cells. SCC- 4 cells $\left(1.5 \times 10^{6}\right.$ cells/dish) were treated with $\mathrm{K} 87(0$ and $2.5 \mu \mathrm{M})$ for $0,2,4$ and $8 \mathrm{~h}$. Nuclear extracts from each sample and protein concentration was measured for EMSA (A). After cells were treated with $\mathrm{K} 87(2.5 \mu \mathrm{M})$ for 2,4 and $8 \mathrm{~h}$, cells were harvested and cytosolic and nuclear extracts were performed for examining the protein expression such

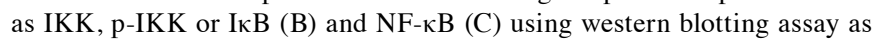
described in Materials and methods.

K87 is a synthesized chemical and not known to exhibit anticancer property by inhibiting cancer cell growth, migration and invasion. Our studies investigated that K87 significantly suppressed the mobility, migration and invasion of SCC-4 cells, which did not result from cell growth arrest, because we selected low concentrations of $\mathrm{K} 87(0-2.5 \mu \mathrm{M})$ throughout the experiments. Our findings indicated that K87 treatment strongly attenuated the cell migration and invasion of SCC-4 cells through downregulation of $M M P-2,-7, F A K$ and ROCK1 mRNA (Fig. 4) and protein levels and MMP-2 


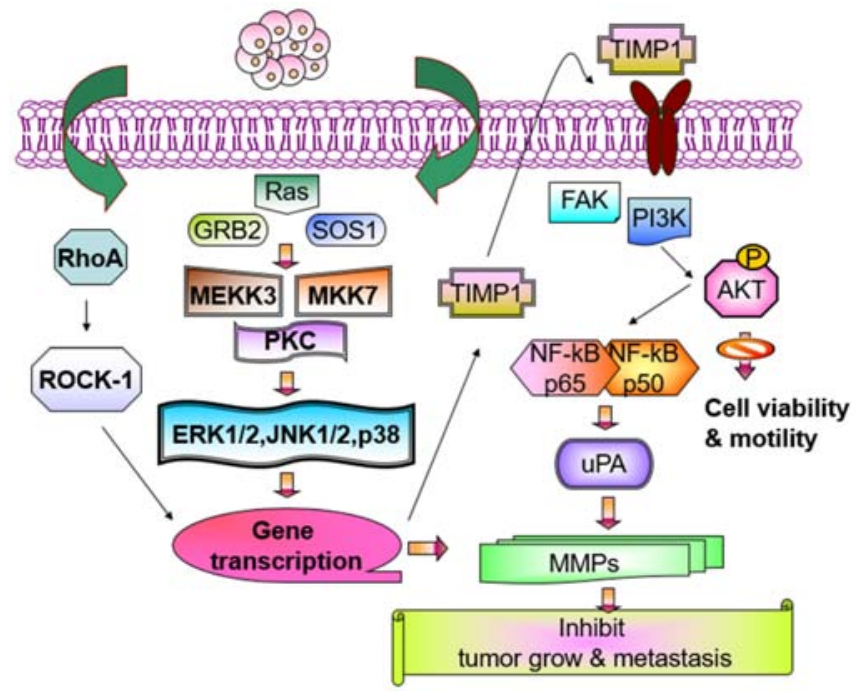

Figure 7. The possible signaling pathways for K87-inhibited migration and invasion of SCC-4 human oral cancer cells.

and -9 activities, as well as inhibition of NF- $\mathrm{BB}$. MMPs play an important role in degradation of matrix barriers surrounding the tumor, for tumor growth, invasion, angiogenesis and metastasis (42-45). When undergoing tumor growth and invasion, both MMP-2 and MMP-9 are involved in the initial breakdown of collagen and basement membrane components (38), thus, the inhibition of MMP expression and activity that may lead to suppressed tumor invasion and migration. K87 inhibited MMP-2 and -9 protein expression (Fig. 3B) and MMP-2 mRNA expression (Fig. 4) that may lead to suppress migration and invasion of SCC-4 cells. MMP-9 is abundantly expressed in breast cancer cells and is associated with cell invasion and metastasis (46). MMP-2/-9 are the potential targets for anti-metastatic drug function (47). K87 suppressed the activities of MMP-2 and -9 (Fig. 2G), inhibited the mRNA (Fig. 4) and protein expression (Fig. 3B) of FAK in SCC-4 cells. FAK was reported to be involved with MMP-9 production in cholangiocarcinoma (48).

Three major MAPKs (p38, JNK and ERK1/2) are the signal transducers involved in cell survival, apoptosis and cell differentiation (49). K87 inhibited the protein expression of ERK1/2, JNK1/2 and p38 (Fig. 3D) which indicated a role for the MAPK signaling pathway in the regulation of cell migration and invasion of SCC-4 cells. K87 suppressed the protein expression of PI3K and Akt in SCC-4 cells (Fig. 3C and $\mathrm{E}$ ). The PI3K/Akt signaling pathway is implicated in cell migration and invasion $(50,51)$ especially in the metastasis of prostate cancer $\mathrm{CaP}$ cells (52). The PI3K-AKT signaling pathways are involved in MMPs for UPA gene regulation, cell survival and cell invasion $(53,54)$.

$\mathrm{NF}-\kappa \mathrm{B}$ plays an important role in the cell proliferation, apoptosis, carcinogenesis, invasion and metastasis (55). The transcriptions of MMP-2/-9 genes are regulated by upstream regulatory factors including $\mathrm{NF}-\kappa \mathrm{B}$ p65 and c-Jun $(56,57)$. Constitutively active PI3K and NF- $\kappa \mathrm{B}$ signaling pathways (58) and blocking PI3K/AKT and NF- $\kappa \mathrm{B}$ signaling pathways led to decrease breast cancer cell migration (59). We have found the inhibition of MM-2/-9 activities (Fig. 2G) and protein

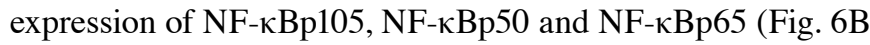
and $\mathrm{C}$ ) and $\mathrm{NF}-\kappa \mathrm{B}$ binding DNA (Fig. 6A) in SCC-4 cells. MMPs are regulated primarily through $N F-\kappa B$ at the level of transcription through PI3K/Akt pathway $(60,61) . N F-\kappa B$ is constitutively activated through a PI3K-dependent activation of IKK $(62,63)$. The K87-mediated suppression of $N F-\kappa B$ in SCC-4 cells probably offers a molecular basis for its ability to inhibit cell migration and invasion.

The present study showed that K87 inhibited cell mobility, invasion and migration of SCC-4 cells by regulating the activities of MMP-2 and -9. K87 inhibited the MAPK (p38, ERK and JNK) signaling pathway by reducing AKT/PI3K, and NF- $\mathrm{Bp} 65$ leading to MMP-2/-9 downregulation as summarized in Fig. 7. Based on these observations, we suggested that K87 inhibited the migration and invasion of SCC-4 cells via the inhibition of MAPK and NF- $\mathrm{BB}$ signaling pathways.

\section{Acknowledgements}

The present study was supported by the grants CMU103ASIA-01 by the China Medical University, Taichung, in part by the Taiwan Ministry of Health and the Welfare Clinical Trial and Research Center of Excellence (MOHW105TDU-B-212-133019) and by the CMU under the Aim for Top University Plan of the Ministry of Education, Taiwan. The experiments and data analysis were performed in part through the use of the Medical Research Core Facilities Center, Office of Research \& Development at China Medical University, Taichung, Taiwan.

\section{References}

1. Deshpande AM and Wong DT: Molecular mechanisms of head and neck cancer. Expert Rev Anticancer Ther 8: 799-809, 2008.

2. Tsantoulis PK, Kastrinakis NG, Tourvas AD, Laskaris G and Gorgoulis VG: Advances in the biology of oral cancer. Oral Oncol 43: 523-534, 2007.

3. Fan S, Tang QL, Lin YJ, Chen WL, Li JS, Huang ZQ, Yang ZH, Wang YY, Zhang DM, Wang HJ, et al: A review of clinical and histological parameters associated with contralateral neck metastases in oral squamous cell carcinoma. Int J Oral Sci 3: 180-191, 2011.

4. Khan N and Mukhtar H: Cancer and metastasis: Prevention and treatment by green tea. Cancer Metastasis Rev 29: 435-445, 2010.

5. Ying H, Biroc SL, Li WW, Alicke B, Xuan JA, Pagila R, Ohashi Y, Okada T, Kamata Y and Dinter H: The Rho kinase inhibitor fasudil inhibits tumor progression in human and rat tumor models. Mol Cancer Ther 5: 2158-2164, 2006.

6. Woessner JF Jr: Matrix metalloproteinases and their inhibitors in connective tissue remodeling. FASEB J 5: 2145-2154, 1991.

7. Chambers AF and Matrisian LM: Changing views of the role of matrix metalloproteinases in metastasis. J Natl Cancer Inst 89: 1260-1270, 1997.

8. Velinov N, Poptodorov G, Gabrovski N and Gabrovski S: The role of matrixmetalloproteinases in the tumor growth and metastasis. Khirurgiia (Sofiia): 44-49, 2010 (In Bulgarian).

9. Ram M, Sherer Y and Shoenfeld Y: Matrix metalloproteinase-9 and autoimmune diseases. J Clin Immunol 26: 299-307, 2006.

10. Brinckerhoff CE and Matrisian LM: Matrix metalloproteinases: A tail of a frog that became a prince. Nat Rev Mol Cell Biol 3: 207-214, 2002.

11. Itoh $\mathrm{Y}$ and Nagase $\mathrm{H}$ : Matrix metalloproteinases in cancer. Essays Biochem 38: 21-36, 2002.

12. Helbig G, Christopherson KW II, Bhat-Nakshatri P, Kumar S, Kishimoto H, Miller KD, Broxmeyer HE and Nakshatri $\mathrm{H}$ : NF-kappaB promotes breast cancer cell migration and metastasis by inducing the expression of the chemokine receptor CXCR4. J Biol Chem 278: 21631-21638, 2003. 
13. Koyama S: Differential expression of intracellular apoptotic signaling molecules in tumor and tumor-infiltrating lymphocytes during development of invasion and/or metastasis of gastric carcinoma. Dig Dis Sci 48: 2290-2300, 2003.

14. Pai SI and Westra WH: Molecular pathology of head and neck cancer: Implications for diagnosis, prognosis, and treatment. Annu Rev Pathol 4: 49-70, 2009.

15. Pikarsky E, Porat RM, Stein I, Abramovitch R, Amit S, Kasem S, Gutkovich-Pyest E, Urieli-Shoval S, Galun E and Ben-Neriah Y: NF-kappaB functions as a tumour promoter in inflammationassociated cancer. Nature 431: 461-466, 2004.

16. Wang CY, Mayo MW and Baldwin AS Jr: TNF- and cancer therapy-induced apoptosis: Potentiation by inhibition of NF-kappaB Science 274: 784-787, 1996.

17. Aggarwal BB: Nuclear factor-kappaB: The enemy within. Cancer Cell 6: 203-208, 2004.

18. Ghosh S and Karin M: Missing pieces in the NF-kappaB puzzle. Cell 109 (Suppl): S81-S96, 2002.

19. McNulty SE, Tohidian NB and Meyskens FL Jr: RelA, p50 and inhibitor of kappa B alpha are elevated in human metastatic melanoma cells and respond aberrantly to ultraviolet light B. Pigment Cell Res 14: 456-465, 2001.

20. Park BK, Zhang H, Zeng Q, Dai J, Keller ET, Giordano T, Gu K, Shah V, Pei L, Zarbo RJ, et al: NF-kappaB in breast cancer cells promotes osteolytic bone metastasis by inducing osteoclastogenesis via GM-CSF. Nat Med 13: 62-69, 2007.

21. Sasaki N, Morisaki T, Hashizume K, Yao T, Tsuneyoshi M, Noshiro H, Nakamura K, Yamanaka T, Uchiyama A, Tanaka M, et al: Nuclear factor-kappaB p65 (RelA) transcription factor is constitutively activated in human gastric carcinoma tissue. Clin Cancer Res 7: 4136-4142, 2001.

22. Shishodia S and Aggarwal BB: Nuclear factor-kappaB activation mediates cellular transformation, proliferation, invasion angiogenesis and metastasis of cancer. Cancer Treat Res 119: 139-173, 2004.

23. Liptay S, Weber CK, Ludwig L, Wagner M, Adler G and Schmid RM: Mitogenic and antiapoptotic role of constitutive NF-kappaB/Rel activity in pancreatic cancer. Int J Cancer 105: 735-746, 2003.

24. Aguirre Ghiso JA, Alonso DF, Farías EF, Gomez DE and de Kier Joffè EB: Deregulation of the signaling pathways controlling urokinase production. Its relationship with the invasive phenotype. Eur J Biochem 263: 295-304, 1999.

25. Westermarck J and Kähäri VM: Regulation of matrix metalloproteinase expression in tumor invasion. FASEB J 13: 781-792, 1999.

26. Mannello F, Tonti G and Papa S: Matrix metalloproteinase inhibitors as anticancer therapeutics. Curr Cancer Drug Targets 5: 285-298, 2005.

27. Yu FS, Huang AC, Yang JS, Yu CS, Lu CC, Chiang JH, Chiu CF and Chung JG: Safrole induces cell death in human tongue squamous cancer SCC-4 cells through mitochondria-dependent caspase activation cascade apoptotic signaling pathways. Environ Toxicol 27: 433-444, 2012

28. Jao HY, Yu FS, Yu CS, Chang SJ, Liu KC, Liao CL, Ji BC, Bau DT and Chung JG: Suppression of the migration and invasion is mediated by triptolide in B16F10 mouse melanoma cells through the NF-kappaB-dependent pathway. Environ Toxicol: Sep 29, 2015 (Epub ahead of print). doi: 10.1002/tox.22198.

29. Chang YM, Velmurugan BK, Kuo WW, Chen YS, Ho TJ, Tsai CT, Ye CX, Tsai CH, Tsai FJ and Huang CY: Inhibitory effect of alpinate Oxyphyllae fructus extracts on Ang II-induced cardiac pathological remodeling-related pathways in $\mathrm{H} 9 \mathrm{c} 2$ cardiomyoblast cells. Biomedicine 3: 148-152, 2013.

30. Lai KC, Hsu SC, Kuo CL, Ip SW, Yang JS, Hsu YM, Huang HY, Wu SH and Chung JG: Phenethyl isothiocyanate inhibited tumor migration and invasion via suppressing multiple signal transduction pathways in human colon cancer HT29 cells. J Agric Food Chem 58: 11148-11155, 2010.

31. Lai WW, Hsu SC, Chueh FS, Chen YY, Yang JS, Lin JP, Lien JC, Tsai $\mathrm{CH}$ and Chung JG: Quercetin inhibits migration and invasion of SAS human oral cancer cells through inhibition of $\mathrm{NF}-\kappa \mathrm{B}$ and matrix metalloproteinase-2/-9 signaling pathways. Anticancer Res 33: 1941-1950, 2013

32. Lin SS, Lai KC, Hsu SC, Yang JS, Kuo CL, Lin JP, Ma YS, Wu CC and Chung JG: Curcumin inhibits the migration and invasion of human A549 lung cancer cells through the inhibition of matrix metalloproteinase-2 and -9 and Vascular Endothelial Growth Factor (VEGF). Cancer Lett 285: 127-133, 2009.
33. Lin MC, Tsai SY, Wang FY, Liu FH, Syu JN and Tang FY: Leptin induces cell invasion and the upregulation of matrilysin in human colon cancer cells. Biomedicine 3: 174-180, 2013

34. Lin HJ, Su CC, Lu HF, Yang JS, Hsu SC, Ip SW, Wu JJ, Li YC, Ho CC, Wu CC, et al: Curcumin blocks migration and invasion of mouse-rat hybrid retina ganglion cells (N18) through the inhibition of MMP-2, -9, FAK, Rho A and Rock-1 gene expression. Oncol Rep 23: 665-670, 2010.

35. Liu KC, Huang AC, Wu PP, Lin HY, Chueh FS, Yang JS, Lu CC, Chiang JH, Meng M and Chung JG: Gallic acid suppresses the migration and invasion of PC-3 human prostate cancer cells via inhibition of matrix metalloproteinase-2 and -9 signaling pathways. Oncol Rep 26: 177-184, 2011.

36. Lu KW, Chen JC, Lai TY, Yang JS, Weng SW, Ma YS, Lu PJ, Weng JR, Chueh FS, Wood WG, et al: Gypenosides inhibits migration and invasion of human oral cancer SAS cells through the inhibition of matrix metalloproteinase-2 -9 and urokinaseplasminogen by ERK1/2 and NF-kappa B signaling pathways. Hum Exp Toxicol 30: 406-415, 2011.

37. Lu HF, Tung WL, Yang JS, Huang FM, Lee CS, Huang YP, Liao WY, Chen YL and Chung JG: In vitro suppression of growth of murine WEHI-3 leukemia cells and in vivo promotion of phagocytosis in a leukemia mice model by indole-3-carbinol. J Agric Food Chem 60: 7634-7643, 2012.

38. Li Q, Han Y, Wang C, Shan S, Wang Y, Zhang J and Ren T: MicroRNA-125b promotes tumor metastasis through targeting tumor protein 53-induced nuclear protein 1 in patients with nonsmall-cell lung cancer. Cancer Cell Int 15: 84, 2015.

39. Wu SH, Hsiao YT, Kuo CL, Yu FS, Hsu SC, Wu PP, Chen JC, Hsia TC, Liu HC, Hsu WH, et al: Bufalin inhibits NCI-H460 human lung cancer cell metastasis in vitro by inhibiting MAPKs, MMPs, and NF- $\kappa$ B pathways. Am J Chin Med 43: 1247-1264, 2015.

40. Lin ML, Chung JG, Lu YC, Yang CY and Chen SS: Rhein inhibits invasion and migration of human nasopharyngeal carcinoma cells in vitro by down-regulation of matrix metalloproteinases-9 and vascular endothelial growth factor. Oral Oncol 45: 531-537, 2009.

41. Köhrmann A, Kammerer U, Kapp M, Dietl J and Anacker J: Expression of matrix metalloproteinases (MMPs) in primary human breast cancer and breast cancer cell lines: New findings and review of the literature. BMC Cancer 9: 188, 2009.

42. Coussens LM, Fingleton B and Matrisian LM: Matrix metalloproteinase inhibitors and cancer: Trials and tribulations. Science 295: 2387-2392, 2002

43. Folgueras AR, Pendás AM, Sánchez LM and López-Otín C: Matrix metalloproteinases in cancer: From new functions to improved inhibition strategies. Int J Dev Biol 48: 411-424, 2004.

44. Kessenbrock K, Plaks V and Werb Z: Matrix metalloproteinases: Regulators of the tumor microenvironment. Cell 141: 52-67, 2010.

45. Schütz A, Schneidenbach D, Aust G, Tannapfel A, Steinert M and Wittekind C: Differential expression and activity status of MMP-1, MMP-2 and MMP-9 in tumor and stromal cells of squamous cell carcinomas of the lung. Tumour Biol 23: 179-184, 2002.

46. Wu X, Zhu Y, Yan H, Liu B, Li Y, Zhou Q and Xu K: Isothiocyanates induce oxidative stress and suppress the metastasis potential of human non-small cell lung cancer cells. BMC Cancer 10: 269, 2010.

47. Weng CJ and Yen GC: The in vitro and in vivo experimental evidences disclose the chemopreventive effects of Ganoderma lucidum on cancer invasion and metastasis. Clin Exp Metastasis 27: 361-369, 2010.

48. Rodríguez-Berriguete G, Fraile B, Martínez-Onsurbe $P$, Olmedilla G, Paniagua R and Royuela M: MAP Kinases and Prostate Cancer. J Signal Transduct 2012: 169170, 2012.

49. Yu T, Wu Y, Helman JI, Wen Y, Wang C and Li L: CXCR4 promotes oral squamous cell carcinoma migration and invasion through inducing expression of MMP-9 and MMP-13 via the ERK signaling pathway. Mol Cancer Res 9: 161-172, 2011.

50. Conley-LaComb MK, Saliganan A, Kandagatla P, Chen YQ, Cher ML and Chinni SR: PTEN loss mediated Akt activation promotes prostate tumor growth and metastasis via CXCL12/ CXCR4 signaling. Mol Cancer 12: 85, 2013.

51. Lee YC, Lin HH, Hsu CH, Wang CJ, Chiang TA and Chen JH: Inhibitory effects of andrographolide on migration and invasion in human non-small cell lung cancer A549 cells via downregulation of PI3K/Akt signaling pathway. Eur J Pharmacol 632: 23-32, 2010 . 
52. Yang SF, Chen MK, Hsieh YS, Yang JS, Zavras AI, Hsieh YH, Su SC, Kao TY, Chen PN and Chu SC: Antimetastatic effects of Terminalia catappa $\mathrm{L}$. on oral cancer via a down-regulation of metastasis-associated proteases. Food Chem Toxicol 48: 1052-1058, 2010.

53. Kim D, Kim S, Koh H, Yoon SO, Chung AS, Cho KS and Chung J: Akt/PKB promotes cancer cell invasion via increased motility and metalloproteinase production. FASEB J 15: 1953-1962, 2001.

54. Prabhu L, Mundade R, Korc M, Loehrer PJ and Lu T: Critical role of NF- $\kappa \mathrm{B}$ in pancreatic cancer. Oncotarget 5: 10969-10975, 2014.

55. Vayalil PK and Katiyar SK: Treatment of epigallocatechin-3-gallate inhibits matrix metalloproteinases- 2 and -9 via inhibition of activation of mitogen-activated protein kinases, c-jun and NF-kappaB in human prostate carcinoma DU-145 cells. Prostate 59: 33-42, 2004

56. Cheung LW, Leung PC and Wong AS: Gonadotropin-releasing hormone promotes ovarian cancer cell invasiveness through c-Jun NH2-terminal kinase-mediated activation of matrix metalloproteinase (MMP)-2 and MMP-9. Cancer Res 66: 10902-10910, 2006.

57. Sweeney C, Li L, Shanmugam R, Bhat-Nakshatri $P$, Jayaprakasan V, Baldridge LA, Gardner T, Smith M, Nakshatri H and Cheng L: Nuclear factor-kappaB is constitutively activated in prostate cancer in vitro and is overexpressed in prostatic intraepithelial neoplasia and adenocarcinoma of the prostate. Clin Cancer Res 10: 5501-5507, 2004.
58. Price JT, Tiganis T, Agarwal A, Djakiew D and Thompson EW: Epidermal growth factor promotes MDA-MB-231 breast cancer cell migration through a phosphatidylinositol 3'-kinase and phospholipase C-dependent mechanism. Cancer Res 59: 5475-5478, 1999.

59. Noma N, Asagiri M, Takeiri M, Ohmae S, Takemoto K, Iwaisako K, Minato N, Maeda-Yamamoto M, Simizu S and Umezawa K: Inhibition of MMP-2-mediated mast cell invasion by NF- $\kappa \mathrm{B}$ inhibitor DHMEQ in mast cells. Int Arch Allergy Immunol 166: 84-90, 2015.

60. Arlt A, Gehrz A, Müerköster S, Vorndamm J, Kruse ML, Fölsch UR and Schäfer H: Role of NF-kappaB and Akt/PI3K in the resistance of pancreatic carcinoma cell lines against gemcitabine-induced cell death. Oncogene 22: 3243-3251, 2003.

61. Chen PS, Shih YW, Huang HC and Cheng HW: Diosgenin, a steroidal saponin, inhibits migration and invasion of human prostate cancer PC-3 cells by reducing matrix metalloproteinases expression. PLoS One 6: e20164, 2011.

62. Eccles SA, Box GM, Court WJ, Bone EA, Thomas W and Brown PD: Control of lymphatic and hematogenous metastasis of a rat mammary carcinoma by the matrix metalloproteinase inhibitor batimastat (BB-94). Cancer Res 56: 2815-2822, 1996.

63. Wang W, Abbruzzese JL, Evans DB, Larry L, Cleary KR and Chiao PJ: The nuclear factor-kappa B RelA transcription factor is constitutively activated in human pancreatic adenocarcinoma cells. Clin Cancer Res 5: 119-127, 1999. 